\title{
MedienPädagogik
}

Zeitschrift für Theorie und Praxis der Medienbildung

\section{Understanding Online Media Literacy in Diverse Society}

\author{
Criticism of \#Siberkreasi Movement in Indonesia \\ Wulan Widyasari and Heidrun Allert
}

\begin{abstract}
The number of misinformation cases in online media made the Indonesian government along with volunteers to form a national media literacy movement, named \#SiBerkreasi. However, the understanding of media literacy by the \#SiBerkreasi movement is still limited to the application of rules and not literacy. Using a literature review, this paper criticizes \#SiBerkreasi as a media literacy movement in Indonesia. The analysis starts by critiquing the understanding of media literacy in Indonesia looking at the context of Indonesian diverse society. The results show that media literacy in Indonesia is still understood from a positivism point of view where literacy teaches only what is positive and what is negative. As a result, \#SiBerkreasi movement does not even touch the critical area of how media literacy should be understood in a diverse society. Beyond the \#SiBerkreasi case, this work considers the role of social context and society in creating information.
\end{abstract}

Medienkompetenz in einer heterogenen Gesellschaft. Eine kritische Betrachtung der \#SiBerkreasi Initiative in Indonesien

\section{Zusammenfassung}

Etliche Fälle von Falschinformationen in online Medien bewegten die indonesische Regierung gemeinsam mit Freiwilligen dazu, eine nationale Medienkompetenz Initiative, \#SiBerkreasi genannt, zu starten. Allerdings ist das zugrundeliegende Verständnis von Medienkompetenz reduziert auf die Idee der Anwendung von Regeln und ist nicht befasst mit der Frage was literacy bedeutet. Basierend auf einer Literaturanalyse untersucht der vorliegende Beitrag das Verständnis von Medienkompetenz, das der \#SiBerkreasi Initiative in Indonesien zugrunde liegt. Der Fokus liegt dabei auf dem Kontext der diversen Gesellschaft des viertbevölkerungsreichsten Staats der Erde, mit seinen vielfältigen Kulturen, Religionen und ethnischen Gruppen. Das Ergebnis zeigt, dass dem implementierten Konzept von Medienkompetenz, bzw. literacy, ein positivistisches Verständnis der Unterscheidbarkeit von richtig und falschem Inhalt zugrunde liegt und massgebliche Dimensionen von Medienkompetenz nicht berührt. 


\section{Introduction}

Media literacy is to be seen in the context of society. Indonesia, in this case, has a national media literacy movement called \#SiBerkreasi. This movement is strongly focused on defining rules to be followed. Moreover, the idea behind the \#SiBerkreasi movement is still limited to judging what is right and what is wrong. Before we discuss the media literacy movement in question, it is interesting to look at the character of Indonesian society. Back in 1961, the Indonesia government created a national motto to describe the diversity in Indonesia. It's called Bhinneka Tunggal Ika, translated as unity in diversity. Based on Government Regulation (Peraturan Pemerintah) no. 66 the year 1961, unity in diversity means although Indonesia consists of diverse ethnic groups and customs they are one nation, Indonesia. From here we can see that the character of Indonesian society is diverse. Furthermore, diversity also becomes a complex social matter that poses either opportunities or challenges for Indonesia. The Indonesian case works as an example for diverse and heterogeneous societies. Here we take Indonesia as a case to discuss the broader issue of online media literacy as related to its societal context, more specifically: a diverse society.

The issue of media literacy is an issue addressed by governmental actors in many countries. In America for example, a growing number of American states are requiring schools to teach students how to judge information on the internet and social media (Lynn 2018). California is the latest state to pass such a requirement. Governor Jerry Brown signed a law aimed at helping educators to teach students "media literacy» skills as the ability to use critical thinking skills to recognize differences between real and «fake» news. Dodd said that his media literacy efforts were based on a Stanford University study from 2016. It found that 80 percent of U.S. middle school students failed to recognize an advertisement that looked like a real news story (Lynn 2018). We can also see the situation in EU countries. At the opening of the 11th Global Media Forum, speakers stressed the importance of information and media literacy. EU Commissioner Mariya Gabriel said she was personally committed to the fight against disinformation. Thus, she said that media literacy can reinforce the resilience of our societies to disinformation by enabling readers, listeners, and viewers to distinguish reliable, from non-reliable sources of information (Bleiker 2018). Finally, we can see media literacy through the aim of the international workshop on Defending Democracy Through Media Literacy in Taipei, Taiwan. Foreign Minister of Taiwan Joseph Wu said that disseminating disinformation with malicious intent should be rejected and condemned, but restricting media through strict laws and regulations [...] violates the spirit of freedom democracies pride themselves on. So, he suggested that instead of draconian legislation, promoting media literacy is a critical means of safeguarding the populace from societal disintegration. Furthermore, the Digital Minister Tang emphasized Taiwan's leadership in being the first country in the world to incorporate media literacy into its school curriculum, with an eye to fostering, "a new generation 
that does not just believe something but learns to navigate different layers of messages and contribute to society and fact check for errors» (Green 2018).

Thus, we can conclude that the practice of media literacy is often limited to issues surrounding the issue of misinformation on social media. No exception in Indonesia, misinformation was also a major issue that prompted the emergence of the \#SiBerkreasi movement. A group of political and business agents sees Indonesia's diversity as the country's weak point. In their perception, Indonesia can be damaged by frying SARA (tribe, religion, race and inter-class groups) issues. Simply by spreading provocative misinformation with SARA content, chaos will happen (Soesatyo 2017). The \#SiBerkreasi movement saw an imbalance between the rapidly growing internet in Indonesia and the absence of digital media literacy on how to use it. According to \#SiBerkreasi, as a result, social media eventually rampant with the spread of misinformation, cyberbullying and hate speech. Although cyberbullying and hate speech are also included in the \#SiBerkreasi program, the misinformation problem is preferred. This can be seen from how \#SiBerkreasi prioritizes programs to fight misinformation. However, preventing information is not the solution to let alone the purpose of media literacy, as boyd stated, it is going to require a lot more than labeling. It is going to require a cultural change about how we make sense of information, whom we trust, and how we understand our own role in grappling with information (boyd 2018). The purpose of \#SiBerkreasi on how to use media and content is not yet «media literacy», like what Buckingham said, media literacy is often invoked in a spirit of «solutionism» (Buckingham 2016). When media regulation seems impossible, media literacy is often seen as the acceptable answer - and indeed a magical panacea - for all media-related social and psychological ills (Buckingham 2016). Furthermore, the \#SiBerkreasi movement also need to include the context of Indonesia's diverse society in it.

Based on this problem, this article seeks to criticize \#SiBerkreasi as a media literacy movement in Indonesia's diverse society. We analyze \#SiBerkreasi movement using a literature review to answer the following question: How is the understanding of online media literacy in Indonesia's diverse society? In an exemplary way this case shows how media literacy and societal diversity are related. In which respect is diversity constitutive in understanding (mis)information? How is societal diversity considered in concepts and models of media literacy? We state that Western societies can learn from Indonesia's immense diversity.

\section{The Case: \#SiBerkreasi}

Currently, the internet and social media play an important role in Indonesia to see how people accept the idea of diversity. Indonesia has substantial internet users. According to statistic data from We Are Social and Hootsuite in January 2017, Indonesia 
is the fastest-growing country concerning the number of internet users today compared to 2016. Indonesia is almost 3 times over the global average with a $51 \%$ growth year-on-year (Nguyen 2017). A survey conducted by the Indonesian Internet Service Provider Association, or APJII, revealed that there are 132.7 million Internet users in the country (Jakarta Globe 2017). General Manager of External Corporate Communication of PT Telkomsel Denny Abidin said, around 34 percent of the internet users are social media users (Purwanto 2017). Furthermore, based on a survey conducted by the Masyarakat Telematika Indonesia (Mastel), social media is the main source of misinformation circulation in Indonesia (Librianty 2017). The peak of misinformation cases in Indonesia is in 2017's Jakarta Election. Following the election, in August, Indonesian police arrested three leaders of an organized fake news syndicate known as Saracen. According to the National Police, Saracen accepted orders from political parties and candidates to make defamatory online content to the tune of 75 million to 100 million Indonesian rupiahs, or about $\$ 5.650$ to $\$ 7.540$, per month (Varagur 2017). Furthermore, according to the police, Saracen syndicate uses Facebook Groups such as Saracen News, Saracen Cyber Team, and Saracennews.com to operates 800,000 social media accounts since November 2015. They spread hate speeches related to ethnicity, religion, races and inter-group relations (BBC Indonesia 2017). For example, the anti-China issue that Saracen actively spreads by making false news about imported workers (DW Indonesia 2017).

Based on the Saracen case, the Indonesia Ministry of Communication and Informatics (KOMINFO) issued a press release number 184/HM/KOMINFO/10/2017 about «Gerakan Nasional Literasi Digital \#SiBerkreasi Ajak Masyarakat Sebar Konten Positif» (National Movement of Digital Literacy \#SiBerkreasi Invites People to Spread Positive Content). In the press release, it said, \#SiBerkreasi emerged from the anxiety of various elements of society against the magnitude of the potential threat of the dangerous spread of «negative content» in cyberspace. The \#SiBerkreasi movement is a collaboration between government and private institutions, communities and digital literacy activists. Because based on data from January 01 until September 18,2017 , the total complaints from people concerning negative content reached 42.821 complaints. Where the first position occupied complaints about hate (13.829), then followed pornography complaints (13.120) and misinformation as many as 6973 complaints (KOMINFO 2017). There is no clear definition of «negative content» other than Minister of Communication and Information Regulation Number 19 of 2014 concerning the handling of negative internet sites which only explains the definition of negative content as pornography and illegal content that is prohibited by law. Nevertheless, the Ministry of Communication and Information will revise the regulation so that the new regulation will contain detailed regulations relating to the contents that may and may not be uploaded by the public (Rosana 2019). 
This \#SiBerkreasi Movement brings two methods against the so-called «negative content» stream. First, is a formal step by incorporating digital literacy knowledge into the school curriculum, from elementary to university level (Agung 2017). Chairman of \#SiBerkreasi Movement, Dedy Permadi said (Herman and FER 2017), they are currently preparing a digital literacy curriculum by synergising materials owned by the community as well as digital literacy activists. After that, they will deliver the results to the Ministry of Education. The digital literacy curriculum aims to make people more intelligent and conscientious in consuming information circulating in cyberspace. The curriculum is expected to be completed by the end of 2017 .

Second, is holding public figures such as artist and KOL (key opinion leader) of social media. This method is deliberately chosen because it is targeting the millennial generation. \#SiBerkreasi movement thinks that public figures and KOL can set a good example for the young generation on the internet. The activities are training to encourage the public to spread «positive content» through the engagement of influencers, from public figures, the formation of communities, volunteers and positive content ambassadors (Wijaya 2017). The \#SiBerkreasi movement invites the influencer voluntarily through two paths (Yusuf 2017). First, is through the organization, for example in collaboration with PARFI (Union of Indonesian Film Artists). Second, is to approach personal influencers. Some things that can be done by the influencers such as creating a video titled «Cek Dulu» (Check It First) for \#SiBerkreasi or give support to a digital startup rather than spreading misinformation.

However, the \#SiBerkreasi as digital literacy movement is still weak to be said as online media literacy. By the press release and media news, it is not clear what digital literacy means by them. It is only stated that the movement uses two approaches. First, social and cultural controls, namely by encouraging people to become more aware and understand the existence of negative content and given understanding and how to treat negative content through socialization and literacy. Second, the participation of the public as well as various institutions through the complaint of negative content by controlling the information technology facility by blocking, closing or deleting content that is potentially inconsistent with the noble norm of the Indonesian nation, and lead to conflict in a society (SiBerkreasi 2017). Of course, if the content is violating rules, it must be deleted. However, it is unclear how the Indonesian government had the conclusion that misinformation is the major problem to be solved by media literacy. Moreover, the government also generalizes the problem of media literacy in diverse Indonesian societies, whereas social contexts such as diversity should be included. 


\section{Method}

Torraco (2016) stated, one of the purposes of the literature review is the use of a literature review to answer specific research questions about a topic. These research questions define the boundaries of the literature to be reviewed and the issues to be examined. We used a literature review to criticize the understanding of online media literacy conducted by \#SiBerkreasi in Indonesia by looking at literature related to media literacy. According to Boote D. N. and Beile P. (2005), a literature review sets the broad context of the study, clearly demarcates what is and what is not within the scope of the investigation, and justifies those decisions.

Furthermore, a literature review method also seeks to identify what has been accomplished previously, allowing for consolidation, for building on previous work, for summation, for avoiding duplication and for identifying omissions or gaps (Grant and Booth 2009). Based on this, using literature review as our method of analysis is suitable for this study because we want to critically analyse media literacy issues in diverse society. The purpose of our literature review method is to deepen understanding of media literacy issues in Indonesia, analyse the development of media literacy issues and concepts, then finally provide suggestion to the existing concepts of media literacy by reflecting diversity issue in order to enhance the media literacy concepts.

To do the analysis, first, we overviewed the case and formulated the research question. Here, we collected the media coverage about \#SiBerkreasi and diversity issues, and use it as the case study. Second, we selected the literature that will be used in our study. Third, we analysed the case using the selected literature. In this study, we analysed \#SiBerkreasi using literatures about media literacy by David Buckingham, Dieter Baacke, Harald Gapski, and W. James Potter. Finally, we concluded to suggest how media literacy should be done in Indonesia's diverse society and how other countries can learn from Indonesia. As stated by Montuori (2005), a literature review involves a survey of the field and as such is an interpretation of that field by the researcher where the researcher decides what authors and theoretical positions to address, how much time to spend on a certain author or a certain theoretical perspective, what to include, and what to leave out of the review based on criteria of relevance. The rationale for a review is to ground the study in appropriate literature, or theoretical or conceptual framework, demonstrating the importance of the topic and the need for the study (Rocco and Plakhotnik 2009).

\section{Misinformation in Diverse Society}

The World Economic Forum once reported, social media increasingly allows information to spread around the world at breakneck speed. While the benefits of this are obvious and well documented, our hyperconnected world could also enable the rapid 
viral spread of information that is either intentionally or unintentionally misleading or provocative, with serious consequences (2013). Thus, it causes the case of misinformation, as Valenzuela et al. stated (2009), using social media for news can lead to the spread of misinformation. In Indonesia, this misinformation is also the reason for the existence of \#SiBerkreasi movement. The Director of Information and Communication of the State Intelligence Agency (BIN) said that according to research, 60 percent of social media content in Indonesia is dominated by misinformation (Kompas. com 2018). These numbers of misinformation finally reached its peak in the last presidential election which caused the Indonesian government to temporarily shut down social media services. The action was taken by the government to avoid spreading misinformation (Safitri 2019). However, the temporary shut down is not a solution. According to the study conducted by Shin et al. (2018), detecting misinformation is challenging because the list of suspicious websites may never be complete due to a constant stream of new players.

Furthermore, to prevent the spreading of misinformation, aside from the government, \#SiBerkreasi also provides solutions by encouraging the public to always read, study, and respond when receiving information both on social media and instant messaging application. Then when in doubt about seeing a piece of information, the public is advised to check facts through trusted fact-checking sites such as stophoax. id, cekfakta.com and turnbackhoax.id. Furthermore, the public is asked to increase digital literacy as a solution to handling «negative content» (HS 2019). In fact, this is also not a solution. As Kuklinski et al. (2000) said, from a misinformation perspective, people's preferences should be hard to change. Their study findings found that rather than respond willy-nilly to whatever cues the environment provides, people resist change. Unless they are «hit between the eyes» with the right facts, they continue to judge policy based on their mistaken beliefs. Their findings are also supported by Nyhan and Reifler (2010) who argued that the responses to corrections in mock news articles differ significantly according to subjects' ideological views. As a result, the corrections fail to reduce misperceptions for the most committed participants. Even worse, they strengthen misperceptions among ideological subgroups in several cases. A study conducted by Thorson (2016) also found that even when misinformation is debunked, it creates problems. First, some people may not believe the correction, instead of maintaining their belief in the false information. Second, the possibility that exposure to corrected misinformation may create effects on attitudes that persist despite an effective correction. Finally, the overall impact of fact-checkers does not depend on selective exposure, which implies that fact-checkers do not have strong effects on people who would avoid them if they could (Hameleers and van der Meer 2019). Here, we can argue that in those approaches, (mis)information is conceptualized as a self-contained unit. We will question this concept of misinformation in the following. As Karlova and Fisher (2012) said, information does not form 
in a vacuum. Social, cultural, and historical aspects may influence how information, misinformation, disinformation, cues to credibility, and cues to deception are perceived and used. For the misinformation term itself, it is about more than news, it is about the entire information ecosystem and complexity of the different types of misinformation (Wardle 2017).

Addressing the misinformation issue, we can refer to a report from the World Economic Forum (2014). It stated that every case of misinformation is unique and should be considered independently, paying attention to the complexities of the ecosystem it circulates within. In terms of interpreting misinformation, a human evaluation will remain essential to put information into context, and context is ultimately what this is all about. In this case, we must take into account the diversity of Indonesian society. We can understand that the information is not isolated and will not take for granted that there is something like information as an entity, which can be checked. It is not about right or wrong but it is in the context in which the information exists because social context and information are entangled. As Buckland (1991) found in his study, people are informed not only by intentional communication but by a wide variety of objects and events. Being «informative» is situational and it would be rash to a state of anything that might not be informative, hence information, in some conceivable situation. It becomes more complex when we also deal with people's beliefs when they get information, as Lazer et al. (2018) stated, individuals, tend not to question the credibility of information unless it violates their preconceptions or they are incentivised to do so. People also tend to align their beliefs with the values of their community. Furthermore, the complexity of information makes the problem of misinformation need to be understood in a context. One of the biggest challenges in addressing the problem of misinformation is the multiplicity of elements involved in the process of production and consumption of misinformation (Karduni 2019).

Thus, Indonesia's diverse society as the context of how media literacy must take its role, instead of focusing on misinformation as an entity. As Baacke (1996) said, media literacy insists on such social and cultural objectives and, properly understood, requires their implementation in education, but also in the extracurricular field. Here, media literacy is understood as media criticism, and this in three ways:

1. Analytically, problematic social processes (e.g. concentration movements) should be adequately grasped. Media literacy then means: Going beyond analysing «information» towards analysing social processes in which information is created. The information and social process are co-produced.

2. Reflexively, every person should be able to apply the analytic knowledge to himself and his actions. Here, media literacy takes a role not only in the level of discourse but also to make people do some actions. 
3. Ethically, people should be able to coordinate and define analytical thinking and reflexive reference as socially responsible. It means media literacy must be able to teach people, not only to do analysis or reflection of the information but also to take responsibility for the information they create.

\section{Media Literacy Concepts and Diversity}

Before we discuss the issue of media literacy in Indonesia's diverse society, we must understand the media literacy concepts from the perspective of David Buckingham, Dieter Baacke, Harald Gapski, and W. James Potter. We also need to understand how diversity take into accounts on their perspectives. First, we can look the media literacy concept by David Buckingham. Literacy is a phenomenon that is only realized in and through social practices of various kinds, and it, therefore, takes different forms in different social and cultural contexts. In studying literacy, we cannot confine our attention to the isolated encounter between the reader and the text. We need to take account of the interpersonal context in which that encounter takes place (where the text is read, with whom, and why), and the broader social and economic processes that determine how texts are produced and circulated (Buckingham 2007). Furthermore, according to Luke (in Buckingham 2007), when we describe somebody as a «literate» person, we do not simply mean that he or she can read and write. Literacy in this broader sense involves analysis, evaluation, and critical reflection. It entails the acquisition of a meta-language - that is, a means of describing the forms and structures of a particular mode of communication, and it involves a broader understanding of the social, economic and institutional contexts of communication, and how these affect people's experiences and practices. It means, before conducting media literacy, we must research the community which will be given an understanding of media literacy. In the concept of media literacy put forward by Buckingham there is a concept of diversity in it. He stressed the need for social diversity in literacy practices which previously tended to be ignored. However, the intended practice of social diversity is limited to inequalities in access between different social and cultural groups, not merely in terms of physical access to equipment, but also in terms of relevant cultural capital (Buckingham 2007).

Second, we can look on Dieter Baacke's work. According to his work, we are now examining the entire media development under the key question of media education, to what extent the media can open up possibilities for action, improve aesthetic experiences and even make children and adolescents sociable for public discourse and thus for political thinking and action. That is, understand the current media issues must be with the media education that allows children to parents to discuss, analyse up to perform actions that will be required (Baacke 1996). Furthermore, he also stated that media literacy is cross-border insofar as it begins in the family, but 
continues in school and also involves the self-learning of peers or the self-educated subject, not to forget adults and old people. This should be made possible by a comprehensive concept of action, which relates interactions and communication in and outside of media, under the guideline of «competence». This term is serious because it formulates an anthropological requirement and at the same time a target for media education (Baacke 2007). Although Baacke did not explicitly mention diversity in his concept of media literacy, he emphasized the concept of individual competencies for the people in order to assert themselves in the information society and not have to float aimlessly through the information seas (Baacke 2007).

Third, we can look on Harald Gapski's concept. He separates the media literacy into several discourses, they are educational, political, sociopolitical and legal discourses (Gapski 2009). Understanding these four points are important to understand media literacy as a cross-sectional social issue that requires interdisciplinary, multidiscursive, and no one-dimensional approach. Any use of media does not take place in free space but is integrated into organisational, social contexts and subject to social conditions. Media literacy thus affects not only individuals but also social systems (schools, companies, authorities) as actors in the respective social areas. In his work, he also did not mention the diversity concept explicitly. He only said about diversity of media technology and social contexts that is subject to social conditions. Gapski (2009) stated that media literacy affects not only individuals, but also social systems (schools, enterprises, men, authorities) as actors in the respective social areas.

Finally, we can see the work of W. James Potter. According to Potter (2016), everyone holds many beliefs about media. Some of these beliefs are accurate but many are faulty. These traps lead people to talk in a circle, and this prevents them from moving forward to a point where they can use media literacy to improve their own lives. The traps are: getting caught in the belief that the media are harmful so the purpose of media literacy is to get us to avoid all media or at least help us avoid the risks of harm, thinking about media literacy is that requires a lot of dry analysis and that will destroy a person's experience of fun with the media, thinking that media literacy is more focused on knowledge than on facts, people often talk about media literacy as if it is simply being critical of the media and believing that it requires too much effort because there is so much involved in becoming media literate. In his work, Potter addressed diversity concept in the media audience segmentation. He mentioned about geographic, psychographic and demographic segmentation, such as gender, ethnic background, age income and education (Potter 2016). The diversity is being applied as knowledge of structure that provide context when trying to make sense of media message. Here, diversity play it role as background experience that form the understanding of media. 
The \#SiBerkreasi, Media Literacy and Diversity Issues

Indonesia does not have a formal literacy concept, let alone the media literacy concept. Understanding of literacy in Indonesia is understood literally, limited to the willingness to read and write. Some news about literacy in Indonesia has always raised the background of the problem of low literacy due to the lack of willingness of the community to read and write. As in the news Tempo.co (Amelia 2017), which describes the number of teachers who are lazy to read to be one cause of the level of literacy in Indonesia is low. In fact, literacy can be interpreted more than just reading and writing.

In the context of media literacy in Indonesia, it is interesting to see how media education plays a role in this country. Media education in Indonesia is given to limited circles, only for students who majored in communication and has not touched the wider community. Nevertheless, media education is still a big challenge in Indonesia, especially when it comes to the education system. As Rosser (2018) argued, the reasons why Indonesia has so far failed to develop a high-quality education system capable of producing strong learning outcomes has not simply been a matter of inadequate funding, human resource deficits, perverse incentive structures, and poor management. It has fundamentally been a matter of politics and power. Indonesia had experienced an authoritarian system for 30 years during the New Order era under the Soeharto regime. This regime forms the character of Indonesian education that is still applied in society. Education in Indonesia is still teacher-centered. Furthermore, this regime also has a big impact on media, whereas, at that time, media has no freedom. Only after the Reform Era, media has freedom of the press. As stated by Nugroho and Syarief (2012), the media sector enjoyed freedom, untying itself from state control, only to become one of the most commercialized sectors in Indonesia. However, the development of the media sector has also enabled the citizens to directly participate in the creation of the content and to reclaim the civic public sphere that was once captured by state-controlled media. So, it is necessary to map the problem of media literacy in Indonesia by looking at the social context in which society is and media education is conducted. So, when the Indonesian government formed \#SiBerkreasi, it was like a solution to the problem.

\#SiBerkreasi is part of a multi-stakeholder commitment to increase media literacy in the community through an invitation to share "creativity of positive content» and «use» the Internet wisely and responsibly (KOMINFO 2017). The \#SiBerkreasi movement also encourages people to actively participate in spreading positive content over the internet and more productively in the digital world (Siberkreasi 2017). The interesting thing about the \#SiBerkreasi Movement is, it also supported by the Ministry of National Education and Culture, the Ministry of State Secretary, Indonesian Broadcasting Commission, Creative Economy Agency and various communities such as Internet Governance Forum, ICT Watch, PANDI , Nawala.org, Indonesia Child 
Online Protection, RAS and Sejiwa Foundation, Internet Sahabat Anak, IWITA Jakarta, ID Talent, Sebangsa, PARFI 56, Center for Digital Society Gadjah Mada University, Indonesian ICT Volunteers, MAFINDO, Japelidi and Layaria (Kompas.com 2017). The \#SiBerkreasi Movement was finally inaugurated on 02 October 2017 at Aula Dewan Nasional 45, a place in Jakarta Pusat. But before that, the \#SiBerkreasi Movement was launched at the Kick- Off Smart Schools Online event on September 24th, 2017 at FX Plaza, a place in Jakarta (Fisipol UGM 2017). This activity is a simultaneous movement in 10 cities namely Jakarta, Sukabumi, Semarang, Jember, Polewali Mandar, Sinjay, Padang, Bojonegoro, Bandung and Papua with the theme „Aku Netizen Unggul« (I'm a Superior Netizen). The so-called «healthy internet campaign» is packed with educational games in the form of a giant «healthy internet» ladder snake. This game contains a "positive message» in each box about understanding the healthy internet, for example: how to cope with the dangers of negative internet content, parental control tips on children's social media activities and anticipation of misinformation (Affrizal 2017).

Furthermore, «healthy» internet means fighting negative content with positive content. Based on a press release issued by \#SiBerkreasi (Siberkreasi 2017), the «negative contents» in question are misinformation, hate speech, cyberbullying and online radicalism that is potentially consumed by internet users. "Positive contents» are like creative workshops, annual awards to appreciate young creators, positive campaign videos on social media and sharing knowledge on how to recognize and not be trapped by fake news. Whereas, what is meant by positive and negative content here is still unclear. The Ministry of Communication and Information stated that they will directly block the content on the internet if it contains two elements, namely pornography, and gambling. But for a variety of other negative content, such as terrorism and illegal drugs, they will communicate first with other agencies (Librianty 2017). As an addition, the Ministry also issued a list of negative content complaints that can be reported by the community. It means people can report any negative content to the ministry through \#SiBerkreasi. Among other things: electronic information/documents that violate the laws and regulations (such as pornography or child pornography, gambling, extortion, fraud, violence or child violence, defamation, intellectual property violations, products with special rules, SARA (ethnic groups, religion, racial and inter-class) provocation, fake news, terrorism or radicalism and electronic information/documents that violate the Act), electronic information/ documents that violate social norms prevailing in society (such as electronic information/documents which does not comply with the values of propriety for public display) and certain electronic document/information that makes blocked negative content accessible such as web proxies, open proxies, open browsers and others (Kumparan 2018). The Indonesian Ministry of Communication and Informatics has also operated a negative content-feeding machine where it will receive certain keywords and within five to ten minutes can block negative social media sites (DW Indonesia 2018). 
Although there are negative content lists that have been released, the labelling of negative content is still subjective. There is no explanation on how to frame negative content. Like, for example, the information statement that disturbs the public, how we can measure information that disturbs the public? Because when we talk about society, we need to look at the social context that exists. The social context is relevant regarding how content on the internet can be considered negative or positive. Even, the idea of negative and positive content is a positivistic idea, where there is a right and wrong measure. Yet the real problem her is how to make people think critically about media content that exist. Here is the role of media literacy should be. Media literacy is not limited to see which one is right and wrong but rather on educating the public that there is an agenda who makes up the truth, who decides which content is positive and which content is negative. When talking about social phenomena, it is not easy to measure it, let alone to determine positive and negative. Especially in a diverse society like Indonesia. For example, there were pros and cons to the gesture of respect made by officers of the Indonesian Railroad (PT KAI) that became viral on social media. The gesture of respect was done by crossing an arm across the chest and slightly bending the body to the passengers before the train departed. On social media, some people appreciate the gesture of respect. However, some criticized the gesture because it was considered excessive and not in accordance with Indonesian culture. There were also those who judged the officers seemed to lower themselves in front of passengers (Arnani 2018). These pros and cons stems from the diverse cultural backgrounds of Indonesian society, where there is a culture that considers the bending of the body movement as positive and respectful gesture, and there is also a culture that considers it as negative and humility gesture. From this example alone,we have to look and think critically how cultural diversity can sum up diverse perspectives, not just see how social media displays messages.

Also, negative content does not necessarily mean negative if the negative content can make people think critically. If people have got media literacy then they can not only sort out which is a fact checked-information and which is a misinformation, but actually, people can be educated to be able to criticize further such as why the misinformation can appear, what agenda behind the misinformation, what are the main target of the misinformation and so on. The «stop hoax» jargon is for example. The Indonesian Minister of Communication and Information said, to prevent misinformation we only need to delete it (Widiyatmaka 2017). If we only stop misinformation but do not understand it then media literacy will not solve the problem. Whereas what should be done is how to educate the public to evaluate and understand the content following the existing diverse social context. In this case, \#SiBerkreasi movement is still often trapped and misinterpreted. The rise of misinformation in the media became the main focus of the movement. 
As Buckingham (2007) said, while digital media clearly raise new questions and require new methods of investigation, this basic conceptual framework continues to provide a useful means of mapping the fields, they are: how digital media represent the world, rather than simply reflect it, how a truly literate individual is able not only to use language, but also to understand how it works, how people understanding who is communicating to whom, and why and how the awareness of one's position as an audience (reader or user). Here, we also want to address the diversity issue that should take into account. The lack of understanding of who is communicating with whom and why is also a matter of media literacy in a diverse society. Media literacy cannot be done just to patronize without emphasizing the level analysis of diverse society in understanding the media message. Understanding awareness of one's position as an audience needs to be emphasized in the media literacy practice.

Media literacy does not necessarily require to eliminate the content that is considered negative. According to Potter $(2016,17)$, media literacy is not just about fearing the media and worrying about protecting one's self and others form their potentially negative effects. He also said that media literacy is also about developing an appreciation for the many positive things the media offer us, so we need to develop a balanced perspective on the media and their influence. From that sense, media literacy is not just replacing negative content with positive content but rather how to develop people's perspectives to analyse the content and influence of the media. The concern should not be how people are afraid of media content and even eliminating it, but rather how society reacts and criticizes it. Media literacy should not specify which content is negative and which content is positive, but instead, let the community decide on the social context that exists. Because when talking about media content, we have to see where and in what social conditions such content appears. However, we also need to know what underlies the issue of media literacy and on the situation of the community how the issue develops. For example, the misinformation surrounding feminism in Indonesia that led to the Indonesia tanpa Feminis (Indonesia without Feminist) movement on social media. This movement opposes the feminism movement as a value imported from the West and not in accordance with religious norms, that is Islamic value. Their rejection of feminism is based on the statement that «my body does not belong to me, but belongs to Allah SWT» (Walden 2019). Indonesia tanpa Feminis raises the pros and cons among the people. They believe that an anti-feminism movement is based on conservative thinking born of political interests in the name of religion. In order to fight this movement, people start to give media literacy about feminism such as doing fact checking about how the freedom enjoyed by Indonesian women today is the result of feminist struggle. However, fact checking is not enough, it is also necessary to update facts and data because if we are trapped in facts or data that are out of date then our understanding of society will stick on static information only. We also cannot necessarily give understanding 
to diverse societies about feminism using perspectives outside their cultural understanding or even simply providing judgment on which is right and which is wrong. Media literacy here must be able to see the perspectives of the people concerned to improve their critical thinking.

Thus, when dealing with diverse society we should involve various communities in society, not just the government. These communities can help in analysing media literacy issues and then take the appropriate approach in society. For example, different levels of education in society determine how far their understanding of media literacy is. Different communities can encourage public participation in doing media literacy.

\section{Enhancing Online Media Literacy in a Diverse Society}

To answer the research question in this article, it is important to look at how Indonesia's diverse society understand media literacy. Research on media literacy in Indonesia has been done several times, but some of these studies have not shown the problems as well as solutions about media literacy in Indonesia's diverse society. The diversity of Indonesian society raises the number of stereotypes, assumptions, and prejudices that are not necessarily true. Diversity in Indonesia forms diverse media with diverse audiences, but media literacy focuses only on misinformation related to politics. This can be seen from the statement by one of the Regional Police Chiefs in Indonesia, for example, which states that the purpose of misinformation, among others, to form opinions, spread terror, political interests, and earn money. So, the focus of the program is just to form a team of cyber troops as a watchdog to prevent misinformation (Widiyatmaka 2017). This narrow understanding of media literacy is limited to preventing and limiting what is positive and what is negative because online media not only create posts but also create culture. Looking at the Indonesian diverse community, it would be dangerous to only categorize media content to being positive and negative. If it is done, eventually, the emerging culture becomes discriminatory, the majority considered true and the minority is considered wrong. As an example, we can see again the case of Jakarta elections in 2017, where the communities attacked each other without any rational discussion. When we disagree with other groups, we are verbally abused without any argumentative discussion. This issue should be the focus of media literacy in Indonesia, the need for understanding of how to create a critical and rational online media culture by looking at the diverse society context. Likewise, when it relates to misinformation, we cannot do media literacy only by categorizing which one is fact-checked information and which one is misinformation. We should look at how the social context influences people's beliefs in existing information because we can not discuss media literacy without society. In this regard, we must see the diversity of Indonesian society based 
on Bhineka Tunggal Ika (unity in diversity) as a motto of Indonesia. Media literacy in Indonesia should play an important part to strengthen people's understanding of Bhinneka Tunggal Ika. As mentioned above, Indonesia has the shadow of the New Order authoritarian system where uniformity occurs in diversity. Here, \#SiBerkreasi as media literacy needs to consider Bhinneka Tunggal Ika as the civilization of the Indonesian people without claiming each other's truth.

To answer the problem surrounding the understanding of online media literacy in Indonesia's society, we suggest the three components of media literacy from Potter (2016), they are personal locus (goals and drives), knowledge structure (media industries, media audiences, media content, media effects, and the real world) and skill of media literacy (analysis, evaluation, grouping, induction, deduction, synthesis and abstracting). But in addition, we add the social context of Indonesia, which is a diverse society. First, the personal locus on the \#SiBerkreasi movement needs to be reviewed. The main purpose of media literacy is not just to tackle misinformation and negative content on social media. But more emphasized how to build characters that have the skill of media literacy. Media literacy should focus to achieve these goals to develop a culture of analysing media content. As Potter $(2016,21)$ said, the more we know our personal locus and the more we make conscious decisions to shape it, the more the can control the process of media influence on us. Of course, this personal locus needs to consider the context of Indonesia's diverse society. To be able to analyse the media content, people also need to understand the diversity issue.

Second, the \#SiBerkreasi movement should not only focus on providing knowledge about negative online media content like what has been done with seminars, games or workshops, but also should be able to shape the community's knowledge structure. \#SiBerkreasi movement can add a program like training on how to process facts obtained in the media. A diverse society certainly brings a variety of facts. Media literacy should see the online media industry, audience, contents, and real-world, especially in encouraging people to get direct experience so as not to appear stereotype or prejudice when understanding online media messages. To conduct media literacy, we can use these people backgrounds and experiences as maps to tell us where to go to retrieve information that we have previously built into our knowledge structure to provide the context we use when trying to make sense of each new media message. With many highly developed knowledge structures, we could understand the entire span of media issues and therefore be able to «see the big picture» about why the media are the way they are.

Third, the \#SiBerkreasi movement should be able to provide the skill of media literacy and not just limited skills to know which content is negative content or misinformation. 
- The first skill that needs to be emphasized is the analytical skills. Media literacy in Indonesia, first of all, should be able to teach people how to view online media messages as a whole. The public should be able to analyse what elements in the message and what effect it will have on the diverse Indonesian society.

- The second skill is the ability of evaluation. Media literacy needs to teach the public to see the elements that make the media message so people can sort out which elements are important and which are not. Looking at the diversity of society, media literacy in Indonesia should be able to teach society how to fight opinions as well as give opinions following our respective understanding. Besides, the people should be taught to accept different opinions so that if there is a debate does not cause division.

- The third skill is grouping. Media literacy needs to educate the public to know how to compile media messages with one another media so that in the end people can realize the different messages and can see the shortcomings.

- The fourth skill is induction. To prevent faulty belief, media literacy in Indonesia needs to teach a variety of experiences to see messages in the media so that people can know that online media messages, let alone in social media, are highly subjective.

- The fifth skill is a deduction. Media literacy in Indonesia needs to teach how to explain online media messages rationally that is not only limited opinion but also based on facts and data so that people become aware of the effects of media messages.

- The sixth skill is synthesis. Here, media literacy should teach Indonesians to adapt to various media messages, rather than reject them. For example, people have to adapt to the existence of misinformation and not simply delete them so that people can have an attitude toward the content.

- The last skill is abstracting. The \#SiBerkreasi movement needs to teach the people of Indonesia to be able to view online media messages thoroughly and to further forward the message to others to be understood by the diverse society.

Thus, we also can argue that those four skills are not enough, people should understand how the social context influences the media literacy skill. In the context of diverse Indonesian society, we must look at how the social and cultural conditions of the society before we spread the information about media literacy. We can take examples of the pros and cons of the Bill on the Elimination of Sexual Violence. The support for this bill is because some people want the law to prevent more victims of sexual violence in the country (Tobing 2019). Whereas the rejection of this bill is due to the fact that some other people consider the provisions regarding the definition of sexual violence and the scope of criminal acts of sexual violence as being dominant with a liberal perspective that is not in accordance with the values of Pancasila, 
religion, and eastern culture (Movanita 2019). Until now the pros and cons have no solution. This is where the role of \#SiBerkreasi as media literacy movement is needed to provide provisions to the public to be able to critically analyse the media information surrounding this issue without the need to put judgment on which is right and which is wrong.

Another example is the issues of LGBTQ (Lesbian Gay Bisexual Transgender Queer) in Indonesia LGBTQ issue certainly need different approach compared to other countries. The diversity of Indonesian society makes the understanding of LGBTQ issues not easy. Those who against LGBTQ consider LGBTQ is against Indonesian religious and cultural values (Jamil 2016). However, if we look into Indonesian society, LGBTQ has been around for a long time, such as the Bugis tribe in South Sulawesi, which recognizes five sexes, namely men (oroane), women (makunrai), women like men (calabai), women like men (calalai), and not the highest rank of gender who is neither male nor female (bissu). It is just that they are not called LGBTQ. The rejection of LGBTQ by Indonesian people is basically because they consider it a Western culture that is different from Indonesian culture. This is where the role of media literacy becomes crucial, instead of only providing information and data on gender equality and how other countries legalize LGBTQ, media literacy need to interpret LGBTQ by looking at the context of Indonesian culture where LGBTQ has long been merged in local culture and not as a movement originating from outside Indonesia.

Finally, media literacy in Indonesia's diverse society can look back on the national motto Bhinneka Tunggal Ika (unity in diversity) as the civilization of the Indonesian people without claiming each other's truth. It is also important to understand the next article, tan hanna dharma mangrwa, which means the dharma is not ambiguous/different. Bhinneka tunggal ika, tan hanna dharma mangrwa which means above the differences Indonesians still have to be able to develop universal values that see people as human beings, namely humanity itself. Here, other countries can also learn how media literacy faced various challenges by the issue of Indonesia's diverse society where the public is only treated to see one side of information so that the understanding of the information was not comprehensive. Media literacy should be able to educate people, not only to see one side but also to see the other side, wherein the end society can determine their attitude and form the critical culture in online media. Here, media literacy can create critical thinking for media and audiences themselves so that people can have a critical perspective. As stated by Kahne and Middaugh (2011), exposure to diverse perspectives is an essential support for a democratic society, and increasing concerns regarding the partisan nature of civic and political dialog. Digital media literacy activities are strongly associated with higher levels of perceived online exposure to diverse perspectives is also encouraging. Popper (in Kammerl 2014, 30) said, in the digital society, the possibilities of a self- determined lifestyle must be constantly renegotiated. These negotiation processes can 
be understood as a collective and intergenerational project, which must also serve to secure social conditions for the acquisition of discourse skills. Only if it is possible to keep these discourses open for the participation of the growing generation and its interests and to secure the framework conditions for them can socialization in the digital society succeed as enculturation in an open society.

\section{Conclusion}

Understanding media literacy is currently not only an issue in Indonesia. According to Carson and Titcomb (2018), misinformation is now seen as one of the greatest threats to democracy, free debate, and the Western order. In Germany the SWR fakefinder explains with practical tips on how to recognize misinformation. In the case of the allegedly suspended referee, a source check helps: Who spread the message? (Regensburger 2017). It indicates that threats considered harmful in online media are currently focused on misinformation in public discourse and some funding schemes for media education and not how to provide media literacy to the public to be critical - especially in diverse societies such as Indonesia. Media literacy is not enough only to make people know an online media content is a fact-checked information or misinformation, and media literacy can not be done by patronizing where the content is positive and where negative. As Kammerl (2014) said, in the context of the dynamically changing media usage behaviour, an orientation towards the normal behaviour that is statistically determinable beyond the individual discourse seems unsuitable. By looking at the case of \#SiBerkreasi in Indonesia, media literacy needs to make improvements so as not be limited to the understanding of online media content only. It should also be seen how media literacy can be a place for people to learn to be critical and discuss it with a rational argument. We also suggest to make a campaign for media literacy with a diversity insight, which characterizes the Indonesian people, and with the spirit of Bhinneka Tunggal lka (unity in diversity) that appreciate the diversity and appreciate rational criticisms though we are diverse. Finally, we can say that the understanding of media literacy is also important around the world. We can take an example of the «European Media Literacy Week» by the European Commission as a new initiative to underline the societal importance of media literacy and promote media literacy initiatives and projects across the European Union (European Commission 2019).

This paper has limitations. First, it only analyses the media literacy movement in Indonesia from the documents published by \#SiBerkreasi and media coverage. Second, this paper still requires observation data by taking a specific case in Indonesia. So for the next study, it can be done by directly observing the \#SiBerkreasi movement in the community. 


\section{References}

Affrizal. 2017. «Siber Kreasi Bojonegoro, Serempak 10 Kota Kampanyekan Internet Sehat di Car Free Day». Relawan TIK Bojonegoro, 24 September 2017. http://www.rtikbojonegoro.or.id/ siber-kreasi-bojonegoro-serempak-10-kota-kampanyekan-internet-sehat-di-car-free-day/.

Agung, Bintoro. 2017. «Program Literasi Digital Sasar Millenial Demi Tekan Hoax». CNN Indonesia, 3 October 2017. https://www.cnnindonesia.com/teknologi/20171002171758-192-245609/ program-literasi-digital-sasar-millenial-demi-tekan-hoax/.

Amalia, Zara. 2017. «Guru Malas Membaca,Literasi Indonesia Rendah». Tempo.co, 26 December 2017. https://nasional.tempo.co/read/1045341/guru-malas-membaca-literasi-indonesia-rendah.

Arnani, Mela. 2018. "Gestur Hormat Sebelum Kereta Berangkat Menuai Pro-Kontra, Ini Kata PT KAl». Kompas.com, 22 October 2018. https://nasional.kompas.com/ $\mathrm{read} / 2018 / 10 / 22 / 18042151 /$ gestur-hormat-sebelum-kereta-berangkat-menuai-pro-kontra-ini-kata-pt-kai?page=all.

Baacke, Dieter. 1996. «Medienkompetenz - Begrifflichkeit und sozialer Wandel». In Theorie und Praxis der Erwachsenenbildung. Medienkompetenz als Schluesselbegriff, edited by Anja von Rein, 112-24. Germany: Deutschen Institut fuer Erwachsenenbildung (DIE).

Baacke, Dieter. 2007. Medienpädagogik. Vol. 1. Grundlagen der Medienkommunikation. Tübingen: Niemeyer Verlag. https://doi.org/10.1515/9783110938043.

BBC Indonesia. 2017. «Kasus Saracen: Pesan kebencian dan hoax di media sosial «memang terorganisir»». BBC Indonesia, Agustus 2017. http://www.bbc.com/indonesia/trensosial-41022914.

Bleiker, Carla. 2018. «Global Media Forum 2018: Pluralist Media 〈needed More than Ever»». DW News, 11 June 2018. https://www.dw.com/en/global-media-forum-2018-pluralist-medianeeded-more-than-ever/a-44159347.

Boote, David N., and Penny Beile. 2005. «Scholars Before Researchers: On the Centrality of the Dissertation Literature Review in Research Preparation». Educational Researcher 34 (6): 3-15. https://doi.org/10.3102/0013189X034006003.

boyd, danah. 2017. «Did Media Literacy Backfire?» Points, 6 January 2017. https://points.datasociety.net/did-media-literacy-backfire-7418c084d88d.

Buckingham, David. 2007. «Digital Media Literacies: Rethinking Media Education in the Age of the Internet». Research in Comparative and International Education 2 (1): 43-55. https:// doi.org/10.2304/rcie.2007.2.1.43.

Buckingham, David. 2016. «Whatever Happened to Media Literacy?» David Buckingham (blog). 2016. https://davidbuckingham.net/2016/09/20/whatever-happened-to-media-literacy/.

Buckland, Michael K. 1991. «Information as Thing». Journal of the American Society for Information Science 42 (5): 351-60. https://doi.org/10.1002/(SICI)1097-4571(199106)42:5<351::AIDASI5>3.0.CO;2-3. 
Carson, James, and J Titcomb. 2018. «Fake News: What Exactly Is It - and How Can You Spot It?» The Telegraph, 29 January 2018. http://www.telegraph.co.uk/technology/0/fake-newsexactly-has-really-had-influence/.

DW Indonesia. 2017. «Siapa Dalang di Balik Bisnis Fitnah Saracen?» DW Indonesia, 24 August 2017. https://www.dw.com/id/siapa-dalang-di-balik-bisnis-fitnah-saracen/a-40214893.

DW Indonesia. 2018. «Indonesia Berantas Konten Negatif dari Internet». DW Indonesia, 3 January 2018. http://www.dw.com/id/indonesia-berantas-konten-negatif-dariinternet/a-42012736.

European Union. 2019. «European Media Literacy Week». Europa.Eu, 22 March 2019. https:// ec.europa.eu/digital-single-market/en/news/european-media-literacy-week.

Fisipol UGM. 2017. «Gerakan Nasional Literasi Digital \#SiBerkreasi Mengajak Warganet untuk Sebarkan Konten Positif di Dunia Maya». Fisipol UGM Press, 2 October 2017. http://fisipol. ugm.ac.id/news/gerakan-nasional-literasi-digital-siberkreasi-mengajak-warganet-untuksebarkan-konten-positif-di-dunia-maya/id/.

Flyvbjerg, Bent. 2001. Making Social Science Matter. Cambridge University Press.

Gapski, Harald. 2017. «Medienkompetenz als gesellschaftliche Schlüsselkompetenz». In Schlüsselqualifikationen für Studium, Beruf und Gesellschaft: Technische Universitäten im Kontext der Kompetenzdiskussion, edited by Caroline Y. Robertson-von Trotha, 409-26. KIT Scientific Publishing. Karlsruhe: KIT Scientific Publishing. http://books.openedition.org/ $\mathrm{ksp} / 3331$.

Grant, Maria J., and Andrew Booth. 2009. «A Typology of Reviews: An Analysis of 14 Review Types and Associated Methodologies: A Typology of Reviews, Maria J. Grant \& Andrew Booth». Health Information \& Libraries Journal 26 (2): 91-108. https://doi.org/10.1111/j.14711842.2009.00848.x.

Green, David. 2018. «Taiwan Takes Centerstage in Global Fight Against 〈Fake News»». The News Lens, 19 October 2018. https://international.thenewslens.com/article/106412.

Gunia, Jürgen. 2012. «Kompetenz. Versuch einer genealogischen Ideologiekritik». Textpraxis 4 (1): 12. https://doi.org/10.17879/57289578515.

Hameleers, Michael, and Toni G. L. A. van der Meer. 2019. «Misinformation and Polarization in a High-Choice Media Environment: How Effective Are Political Fact-Checkers?» Communication Research, January, 009365021881967 . https://doi.org/10.1177/0093650218819671.

Herman/FER. 2017. «Literasi Digital Didorong Masuk Kurikulum Pendidikan». Berita Satu, 2 October 2017. http://www.beritasatu.com/iptek/455860-literasi-digital-didorong-masukkurikulum-pendidikan.html.

HS, Ranap Tumpal. 2019. «Tangkal Hoaks Bawaslu, Siberkreasi dan Parfi»56 Serukan Medsos Positif». Bawaslu.go.id, 15 April 2019. https://bawaslu.go.id/id/berita/tangkal-hoaks-bawaslu-siberkreasi-dan-parfi56-serukan-medsos-positif.

Jakarta Globe. 2017. «More than Half of Indonesians are Internet Users». Jakarta Globe, 24 October 2017. http://jakartaglobe.id/news/half-indonesians-internet-users/. 
Jamil, Ahmad Islamy. 2016. "HMI: LGBT Bertentangan dengan Nilai Agama dan Budaya». Republika.co.id, 23 January 2016. https://www.republika.co.id/berita/dunia-islam/islamnusantara/16/01/23/o1eer5394-hmi-lgbt-bertentangan-dengan-nilai-agama-dan-budaya.

Kahne, Joseph, Ellen Middaugh, Nam-Jin Lee, and Jessica T. Feezell. 2012. «Youth Online Activity and Exposure to Diverse Perspectives». New Media \& Society 14 (3): 492-512. https:// doi.org/10.1177/1461444811420271.

Kammerl, Rudolf. 2014. «Enkulturationshilfen in der digitalen Gesellschaft Diskurse als/oder Orientierung?»In Jahrbuch Medienpädagogik 11, edited by Rudolf Kammerl, Alexander Unger, Petra Grell, and Theo Hug, 15-33. Wiesbaden: Springer Fachmedien Wiesbaden. https://doi.org/10.1007/978-3-658-06462-4_2.

Karduni, Alireza. 2019. «Human-Misinformation Interaction: Understanding the Interdisciplinary Approach Needed to Computationally Combat False Information». ArXiv:1903.07136 [Cs], March. http://arxiv.org/abs/1903.07136.

Karlova, Natascha A, and Karen E Fisher. n.d. «"Plz RT”: A Social Diffusion Model of Misinformation and Disinformation for Understanding Human Information Behaviour», 17.

KOMINFO. 2017. «Siaran Pers No. 184/HM/KOMINFO/10/2017 about "Gerakan Nasional Literasi Digital \#SiBerkreasi Ajak Masyarakat Sebar Konten Positif”». KOMINFO. https://kominfo. go.id/index.php/content/detail/10801/siaran-pers-no-184hmkominfo102017-tentanggerakan-nasional-literasi-digital-siberkreasi-ajak-masyarakat-sebar-konten-positif/0/siaran_pers.

Kompas.com. 2017. «Gerakan SiBerkreasi Ajak Masyarakat Lawan Hoaks». Kompas.com, 6 October 2017. http://biz.kompas.com/read/2017/10/06/080000628/gerakan-siberkreasiajak-masyarakat-lawan-hoaks.

Kompas.com. 2018. «BIN: 60 Persen Konten Media Sosial adalah Informasi Hoaks». Kompas. com, 15 March 2018. https://nasional.kompas.com/read/2018/03/15/06475551/bin-60-persen-konten-media-sosial-adalah-informasi-hoaks.

Kuklinski, James H., Paul J. Quirk, Jennifer Jerit, David Schwieder, and Robert F. Rich. 2000. «Misinformation and the Currency of Democratic Citizenship». The Journal of Politics 62 (3): 790-816. https://doi.org/10.1111/0022-3816.00033.

Kumparan. 2017a. "Jenis Konten Negatif di Internet yang Bisa Diblokir». Kumparan, Agustus 2017. https://kumparan.com/@kumparantech/jenis-konten-negatif-di-internet-yang-bisa-diblokir.

Kumparan. 2017b. «Ini Cara Seru Komunitas Digital Mencegah Konten Negatif di Internet». Kumparan, 1 November 2017. https://kumparan.com/siber-kreasi/ini-cara-seru-komunitas-digital-mencegah-konten-negatif-di-intenet.

Lazer, David M. J., Matthew A. Baum, Yochai Benkler, Adam J. Berinsky, Kelly M. Greenhill, Filippo Menczer, Miriam J. Metzger, et al. 2018. «The Science of Fake News». Science 359 (6380): 1094-96. https://doi.org/10.1126/science.aao2998. 
Librianty, Andina. 2017a. «Survei: Media Sosial Jadi Sumber Utama Penyebaran Hoax». Liputan 6, 13 February 2017. https://www.liputan6.com/tekno/read/2854713/survei-mediasosial-jadi-sumber-utama-penyebaran-hoax.

Librianty, Andina. 2017b. «Jurus Kemkominfo Blokir Konten Negatif di Internet». Liputan 6, 28 October 2017. http://tekno.liputan6.com/read/3143533/jurus-kemkominfo-blokir-kontennegatif-di-internet.

Lynn, Bryan. 2018. «More US Schools Teaching Skills to Recognize False News». VOA News, 25 September 2018. https://learningenglish.voanews.com/a/more-us-schools-teachingskills-to-recognize-false-news/4586357.html.

Montuori, Alfonso. 2005. "Literature Review As Creative Inquiry: Reframing Scholarship As a Creative Process». Journal of Transformative Education 3 (4): 374-93. https://doi. org/10.1177/1541344605279381.

Movanita, Ambaranie Nadia Kemala. 2019. «Kekeliruan Memahami RUU PKS, Dianggap Liberal dan Tak Sesuai Agama». Kompas.com, 23 September 2019. https://nasional.kompas.com/ $\mathrm{read} / 2019 / 09 / 23 / 19350151 / k e k e l i r u a n-m e m a h a m i-r u u-p k s-d i a n g g a p-l i b e r a l-d a n-t a k-s e-$ suai-agama?page=all.

Nguyen, Han. 2017. «Indonesia Is Fastest Growing Country for Internet Use - Report». Rappler, 26 January 2017. https://www.rappler.com/world/regions/asia-pacific/indonesia/bahasa/ englishedition/159593-internet-social-media-statistics.

Nugroho, Yanuar, and Sofie Shinta Syarief. 2012. Beyond Click-Activism?: New Media and Political Processes in Contemporary Indonesia. Jakarta: Friedrich-Ebert-Stiftung.

Nyhan, Brendan, and Jason Reifler. 2010. «When Corrections Fail: The Persistence of Political Misperceptions». Political Behavior 32 (2): 303-30. https://doi.org/10.1007/s11109-0109112-2.

Potter, W. James. 2010. «The State of Media Literacy». Journal of Broadcasting \& Electronic Media 54 (4): 675-96. https://doi.org/10.1080/08838151.2011.521462.

Potter, W. James. 2016. Introduction to Media Literacy. USA: SAGE Publication.

Purwanto, Heru. 2017. «Internet Users in Indonesia up 51 percent a year». ANTARA News, 13 October 2017. https://en.antaranews.com/news/113060/internet-users-in-indonesia-up51-percent-a-year.

Regensburger, F. 2017. «"Fakefinder” will Blick für Fake-News schärfen». BR.de, 16 August 2017. http://www.br.de/nachrichten/faktencheck/swr-fake-news-finder-faktencheck-100.html.

Rocco, Tonette S., and Maria S. Plakhotnik. 2009. "Literature Reviews, Conceptual Frameworks, and Theoretical Frameworks: Terms, Functions, and Distinctions». Human Resource Development Review 8 (1): 120-30. https://doi.org/10.1177/1534484309332617.

Rosana, Francisca Christy. 2019. «Kominfo akan Atur Konten yang Boleh dan Dilarang Diunggah». Tempo.co, 29 July 2019. https://bisnis.tempo.co/read/1229840/kominfo-akan-aturkonten-yang-boleh-dan-dilarang-diunggah/full\&view=ok. 
Rosser, A. 2008. «Beyond Access: Making Indonesia»s Education System Work». Lowy Institute, 21 February 2008. https://www.lowyinstitute.org/beyond-access-making-indonesia-seducation-system-work.

Safitri, Eva. 2019. "Wiranto: Media Sosial Kita Nonaktifkan Sementara untuk Hindari Hoax». Detik.com, 22 May 2019. https://news.detik.com/berita/d-4560391/wiranto-media-sosialkita-nonaktifkan-sementara-untuk-hindari-hoax.

Shin, Jieun, Lian Jian, Kevin Driscoll, and François Bar. 2018. «The Diffusion of Misinformation on Social Media: Temporal Pattern, Message, and Source». Computers in Human Behavior 83 (June): 278-87. https://doi.org/10.1016/j.chb.2018.02.008.

SiBerkreasi. 2017a. «Tentang SiBerkreasi». SiBerkreasi, 2017. http://siberkreasi.id/tentangsiberkreasi/.

SiBerkreasi. 2017b. «\#SiBerkreasi Netizen Fair 2017 Netizen Berkarya, Cerahkan Dunia Maya». SiBerkreasi, 26 October 2017. http://siberkreasi.id/2017/10/peluncuran-siberkreasi-netizen-fair-2017/.

Soesatyo, Bamgang. 2017. «Mencabik Keberagaman dengan Hoax Provokatif». Koran Sindo, 26 May 2017. https://nasional.sindonews.com/read/1208153/18/mencabik-keberagamandengan-hoax-provokatif-1495757282.

Thorson, Emily. 2016. «Belief Echoes: The Persistent Effects of Corrected Misinformation». Political Communication 33 (3): 460-80. https://doi.org/10.1080/10584609.2015.1102187.

Tobing, Sorta. 2019. «Gagal Paham RUU PKS, Dianggap Pro-LGBT dan Melenceng dari Agama». Katadata, 25 September 2019. https://katadata.co.id/berita/2019/09/25/gagal-pahamruu-pks-dianggap-pro-lgbt-dan-melenceng-dari-agama.

Torraco, Richard J. 2016. «Writing Integrative Literature Reviews: Using the Past and Present to Explore the Future». Human Resource Development Review 15 (4): 404-28. https://doi. org/10.1177/1534484316671606.

Valenzuela, Sebastián, Daniel Halpern, James E. Katz, and Juan Pablo Miranda. 2019. «The Paradox of Participation Versus Misinformation: Social Media, Political Engagement, and the Spread of Misinformation». Digital Journalism 7 (6): 802-23. https://doi.org/10.1080/2 1670811.2019.1623701.

Varagur, Krithika. 2017. "Fake News" Remains a Problem in Indonesia». VOA Indonesia, 21 September 2017. https://www.voanews.com/a/fake-news-indonesia/4038139.html.

Walden, Max. 2019. «Gerakan Anti Feminis Menguat di Indonesia». ABC News, 17 May 2019. https://www.abc.net.au/indonesian/2019-05-27/gerakan-indonesia-tanpa-feminis/11151640.

Wardle, Claire. 2017. «Fake News. It»s Complicated». First Draft, 16 February 2017. https://firstdraftnews.org/fake-news-complicated/. 
Widiyatmaka, Aloysius. 2017. «Pemerintah menggandeng swasta, masyarakat, artis, dan para toloh agama dalam rangka meningkatkan literasi digital dengan meluncurkan siberkreasi». Koran Jakarta, 27 October 2017. http://www.koran-jakarta.com/siberkreasi-untukperangi-berita-bohong/.

Wijaya, Yulius Satria. 2017. «Literasi Digital Wajib Masuk Kurikulum». Media Indonesia, 3 October 2017. http://www.mediaindonesia.com/index.php/news/read/125273/literasi-digitalwajib-masuk-kurikulum/2017-10-03.

World Economic Forum. 2013. «Digital Wildfires in a Hyperconnected World». World Economic Forum. http://reports.weforum.org/global-risks-2013/risk-case-1/digital-wildfires-in-ahyperconnected-world/?doing_wp_cron=1569148276.4777700901031494140625.

World Economic Forum. 2014. «The Rapid Spread of Misinformation Online». World Economic Forum. http://reports.weforum.org/outlook-14/top-ten-trends-category-page/10-therapid-spread-of-misinformation-online/.

Yusuf, Oik. 2017. "Lawan Hoax di Millennial, Gerakan Literasi Nasional Gandeng Selebritas». Kompas.com, 2 October 2017. http://tekno.kompas.com/read/2017/10/02/16060587/lawan-hoax-di-millennial-gerakan-literasi-nasional-gandeng-selebritas.

\section{Funding}

This work was supported by Deutscher Akademischer Austauschdienst e.V. (DAAD) Indonesian German Scholarship Program. 